\title{
Weed Control and Crop Safety with Premixed $S$-Metolachlor and Sulfentrazone in Sunflower
}

\author{
Seshadri S. Reddy ${ }^{1 *}$, Phillip W. Stahlman ${ }^{1}$, Patrick W. Geier ${ }^{1}$, Curtis R. Thompson ${ }^{2}$ \\ ${ }^{1}$ Agricultural Research Center, Kansas State University, Hays, USA; ${ }^{2} 2014$ Throckmorton Hall, Kansas State University, Manhattan, \\ USA. \\ Email: ${ }^{*}$ ssreddy@ksu.edu
}

Received August $16^{\text {th }}, 2012$; revised September $20^{\text {th }}, 2012$; accepted October $7^{\text {th }}, 2012$

\begin{abstract}
A preliminary study conducted in the central USA near Colby and Hays, Kansas (KS) in 2010 indicated a premix of $S$-metolachlor \& sulfentrazone codenamed F7583 $\left(\right.$ Broadaxe $^{\circledR}$ ) had good potential for use in sunflower (Helianthus annuus L.). Additional studies were conducted in 2011 at Colby, Hays, and Manhattan, KS to refine rate and application timing of F7583 for weed control and crop safety. Four rates of F7583 (860, 1100, 1350 and $\left.1840 \mathrm{~g} \cdot \mathrm{ha}^{-1}\right)$ were compared to single rates of $S$-metolachlor and pendimethalin, and applied 21 days preplant versus preemergence (PRE). F7583 at $\geq 1100 \mathrm{~g} \cdot$ ha $^{-1}$ applied preplant or PRE controlled Palmer amaranth (Amaranthus palmeri S. Wats.) and kochia [Kochia scoparia (L.) Schrad.] $\geq 95 \%$ and $100 \%$, respectively in neutral pH soils. In slightly acidic soils, PRE application of F7583 was more effective against Palmer amaranth and grass weeds compared to preplant application. No benefit was gained by increasing the rate of F7583 from 1100 to $1350 \mathrm{~g} \cdot \mathrm{ha}^{-1}$ at either application timing. Puncturevine (Tribulus terrestris L.) control was not commercially satisfactory with F7583 at any rate or time of application. Both $S$-metolachlor at $1070 \mathrm{~g} \cdot \mathrm{ha}^{-1}$ and pendimethalin at $1600 \mathrm{~g} \cdot \mathrm{ha}^{-1}$ applied either preplant or PRE were considerably less effective on all three broadleaf weeds compared to F7583 treatments. Individually, S-metolachlor and pendimethalin were more effective when applied PRE compared to preplant application. F7583 did not reduce sunflower plant population or visibly injure sunflower anytime during the season.
\end{abstract}

Keywords: Broadaxe; Sulfentrazone; S-Metolachlor; Sunflower; Crop Injury; Kochia; Palmer Amaranth

\section{Introduction}

Sunflower (Helianthus annuus L.) is a major oilseed crop in the United States where it was planted on 0.6 million ha in 2011 [1]. North Dakota (0.28 million ha), South Dakota (0.20 million ha) and Kansas (0.05 million ha) are the three major sunflower-growing states in the country. Weeds are one of the major yield limiting factors of sunflower [2]. Canada thistle [Cirsium arvense (L.) Scop.], kochia [Kochia scoparia (L.) Schrad.], redroot pigweed (Amaranthus retroflexus L.), green foxtail [Setaria viridis (L.) Beauv.], and Palmer amaranth (Amaranthus palmeri $\mathrm{S}$. Watson) are among the most common weeds interfering with sunflowers in the central Great Plains [2].

Sunflowers grow slowly the first few weeks after planting which makes the crop vulnerable to weed interference. Johnson (1971) [3] reported maximum seed yields when sunflower was kept weed free 4 to 6 weeks after planting. In the central US Great Plains, most sunflowers are planted in rows spaced greater than $50 \mathrm{~cm}$

${ }^{*}$ Corresponding author. apart [2]. Wide row spacing initially provides weeds an advantage over sunflowers. Durgan et al. (1990) [4] found that season-long competition by kochia at densities of $0.3,1,3$, and 6 plants $\cdot \mathrm{m}^{-1}$ of row decreased sunflower seed yield by $7 \%, 10 \%, 20 \%$, and $27 \%$, respectively. Holman (2004) [5] reported as much as $57 \%$ yield loss in sunflowers due to Persian darnel (Loliumpersicum Boiss. $\&$ Hohen. ex Boiss.) interference. Hence, weed management has great importance in sunflower production.

There are relatively few herbicides registered for use in sunflower. Sulfentrazone belongs to the phenyl triazolinone herbicide group and is a protoporphyrinogen oxidase (PPO) inhibitor [6]. Sulfentrazone is widely used in sunflower in the US for control of broadleaf weeds, but it has little activity on grass weeds. Olson et al. (2011) [7] reported only $57 \%$ and $23 \%$ large crabgrass [Digitaria sanguinalis (L.) Scop.] control in sunflower with sulfentrazone at $105 \mathrm{~g} \cdot \mathrm{ha}^{-1}$ at Manhattan and Hays, KS, respectively. Hence, ulfentrazone is usually tank mixed with $S$-metolachlor or pendimethalin for broad spectrum weed control [8]. The prepacked mixture of $S$-metolachlor \& sulfentrazone $\left(9: 1\right.$ ratio, Broadaxe ${ }^{\mathbb{B}}$, FMC 
Corporation, 1735 Market Street, Philadelphia, PA 19103, USA) received US registration for use in sunflowers in 2012. S-metolachlor belongs to chloroacetamide family of herbicides. The primary mode of action of S-metolachlor is not clear, but the most recent evidence suggests that it blocks the formation of very long chain fatty acids. The objective of the study was to evaluate the premix of $S$-metolachlor \& sulfentrazone (codenamed F7583) for efficacy and safety in sunflowers compared to some commercial standard herbicides.

\section{Materials and Methods}

\subsection{Year I}

A preliminary experiment on $\mathrm{F} 7583$ was conducted at two locations near Colby and Hays, KS in the central USA in 2010. Soil type at Colby was a Keith silt loam with $\mathrm{pH} 7.2$ and $2 \%$ organic matter (OM). At Hays, soil was a Crete silty clay loam with $\mathrm{pH} 6.5$ and $1.5 \% \mathrm{OM}$. Experimental design was a randomized complete block with four treatment replications. Treatments include three rates of $F 7583\left(896,1120\right.$ and $\left.1400 \mathrm{~g} \cdot \mathrm{ai} \cdot \mathrm{ha}^{-1}\right)$ applied PRE to crop and weeds. For comparison, two rates of tank mixed sulfentrazone plus $S$-metolachlor $(90+806$ and $\left.112+1008 \mathrm{~g} \cdot \mathrm{ha}^{-1}\right)$, three rates of sulfentrazone $(90$, 112 and $140 \mathrm{~g} \cdot \mathrm{ha}^{-1}$ ), two rates of $S$-metolachlor (806 and $\left.1008 \mathrm{~g} \cdot \mathrm{ha}^{-1}\right)$ and single rate of pendimethalin (1600 $\mathrm{g} \cdot \mathrm{ha}^{-1}$ ) were also included as PRE treatments. A nontreated control was also included. At Colby, before planting, $120 \mathrm{~kg} \mathrm{~N} \mathrm{ha}^{-1}$ as 32-0-0 liquid fertilizer was applied in early spring and $15 \mathrm{~kg} \cdot \mathrm{N}$ and $45 \mathrm{~kg} \mathrm{P}_{2} \mathrm{O}_{5} \mathrm{ha}^{-1}$ as 10-34-0 liquid fertilizer was injected $5 \mathrm{~cm}$ away and 5 $\mathrm{cm}$ below the seed row at the time of planting. Similarly at Hays, $10 \mathrm{~kg} \mathrm{~N}$ and $30 \mathrm{~kg} \mathrm{P}_{2} \mathrm{O}_{5} \mathrm{ha}^{-1}$ as 10-34-0 liquid fertilizer was injected at the time of planting. Sunflower hybrids Mycogen 8N453DM and 8N386CL were planted no-till into wheat stubble at Colby and Hays, respectively. The seeding rates were 43,200 and 49,000 seeds ha ${ }^{-1}$ at Colby and Hays, respectively, with a row spacing of 76 $\mathrm{cm}$. Plots were 3 by $6.7 \mathrm{~m}$ with four rows of sunflower. Preemergence herbicides were applied immediately after planting using a $\mathrm{CO}_{2}$-powered backpack sprayer delivering $115 \mathrm{~L} \cdot \mathrm{ha}^{-1}$ at $220 \mathrm{kPa}$.

Palmer amaranth, kochia, green foxtail, puncturevine (Tribulus terrestris L.) and tumble pigweed (Amaranthus albus L.) were predominate weed species at Colby. All these weeds except kochia also were predominate at Hays. Weed control was rated 62 and 56 days after planting (DAP) based on composite visual estimations of density reduction, growth inhibition, and foliar injury on a scale of 0 (no effect) to 100 (plant death). Sunflower response was visually rated 14 DAP. Seed yield was determined only at Colby by harvesting the two center rows of each plot with a plot combine and adjusting seed weight to $10 \%$ moisture content.

Data were analyzed using the general linear model procedure of the Statistical Analysis System (Statistical Analysis Systems Institute, Cary, NC, USA) and means were separated at the 5\% significance level using Fisher's protected LSD. Weed control ratings were arcsine transformed before analysis, but original values are presented in this paper. The control treatment was omitted from weed control analyses, but included in the analysis of sunflower seed yield. Data are presented by year or location when significant $(\mathrm{P} \leq 0.05)$ year and or location interactions occurred.

\subsection{Year II}

Field experiments were conducted at three sites in 2011 near Colby, Hays and Manhattan, KS. Soil type at Colby was a Keith silt loam with pH 7.2 and 2\% OM. Soil type at Hays was a Roxbury silt loam with pH 7.8 and 2\% OM and soil type at Manhattan was a Belvue silt loam with pH 6.8 and $1.1 \%$ OM. The experimental design was a randomized complete block with an unbalanced factorial treatment arrangement. Treatments were replicated four times. Treatment structure was modified from year I. However, core treatments of F7583 remained similar with minor changes in application rate. Treatments included four rates of $\mathrm{F} 7583(860,1100,1350$ and 1840 $\left.\mathrm{g} \cdot \mathrm{ha}^{-1}\right)$ and single rates of $S$-metolachlor $\left(1070 \mathrm{~g} \cdot \mathrm{ha}^{-1}\right)$, and pendimethalin $\left(1600 \mathrm{~g} \cdot \mathrm{ha}^{-1}\right)$. All treatments except F7583 at $1840 \mathrm{~g} \cdot \mathrm{ha}^{-1}$ were applied 21 days preplant and PRE (not sequentially). F7583 at $1840 \mathrm{~g} \cdot \mathrm{ha}^{-1}$ was applied only 21 days preplant. A non-treated control also was included. At Colby, $110 \mathrm{~kg} \cdot \mathrm{N} \cdot \mathrm{ha}^{-1}$ was applied as anhydrous ammonia in fall 2010 and was followed by 20 $\mathrm{kg} \mathrm{N}$ and $67 \mathrm{~kg} \mathrm{P}_{2} \mathrm{O}_{5} \mathrm{ha}^{-1}$ in the form of 10-34-0 liquid fertilizer injected $5 \mathrm{~cm}$ away and $5 \mathrm{~cm}$ below the seed row at the time of planting. At Hays, $95 \mathrm{~kg} \cdot \mathrm{N} \cdot \mathrm{ha}^{-1}$ was applied at the time of planting as urea ammonium nitrate. At Manhattan, $80 \mathrm{~kg} \cdot \mathrm{N} \cdot \mathrm{ha}^{-1}$ was applied as urea 9 days after planting. The experimental areas at Colby and Hays were over seeded with Palmer amaranth and kochia before herbicide application. Sunflower hybrids Mycogen 8N435DM, Mycogen 8N358CL and Pioneer 63N82 were planted at Colby, Hays and Manhattan, respectively. Sunflower planting, herbicide application, weed control and crop response ratings and data analyses were done as explained in year I, except the Hays trial was conventionally tilled. Planting and herbicide application dates are shown in Table 1. Weed control was determined 49, 61 and 46 DAP at Colby, Hays and Manhattan, respectively. Crop response was rated 14 DAP at all sites. At Manhattan, seed yield was determined by harvesting the two center rows of each plot with a plot combine and 
Table 1. Sunflower planting and herbicide application dates, 2010 and 2011.

\begin{tabular}{ccccccc}
\hline & & \multicolumn{2}{c}{ Year I } & & \multicolumn{2}{c}{ Year II } \\
\cline { 3 - 7 } & & Colby, KS & Hays, KS & Colby, KS & Hays, KS & Manhattan, KS \\
\hline \multirow{2}{*}{$\begin{array}{c}\text { Planting } \\
\text { Herbicide } \\
\text { application }\end{array}$} & June 10 & June 12 & June 14 & June 17 & June 13 \\
& Preplant & - & - & May 23 & May 27 & May 23 \\
\hline
\end{tabular}

adjusting seed weight to $10 \%$ moisture content. The Colby trial was terminated 7 weeks after planting after severe defoliation and lodging caused by hail. Seed yields of the Hays trial was not determined because of late-season crop damage caused by wildlife.

\section{Results and Discussion}

\subsection{Year I}

Nearly $3.8 \mathrm{~cm}$ rainfall was received at Colby within three days after PRE herbicide application (data not shown). At Hays, a total of $3.6 \mathrm{~cm}$ rainfall was received over a 7 day period after PRE herbicide application. F7583 at 896 $\mathrm{g} \cdot \mathrm{ha}^{-1}$ controlled Palmer amaranth, tumble pigweed, kochia and green foxtail $89 \%, 99 \%, 94 \%$ and $89 \%$, respectively (Table 2). Tank-mixed sulfentrazone plus $S$-metolachlor at $90+806 \mathrm{~g} \cdot \mathrm{ha}^{-1}$ was similarly effective on all species compared to F7583 at $896 \mathrm{~g} \cdot \mathrm{ha}^{-1}$. Increasing F7583 rate from 896 to $1120 \mathrm{~g} \cdot \mathrm{ha}^{-1}$ and tank mix rates of sulfentrazone plus $S$-metolachlor from $90+806$ to $112+$ $1008 \mathrm{~g} \cdot \mathrm{ha}^{-1}$ did not improve weed control. This indicates that at equivalent rates of active ingredient, the premixed and tank-mixed treatments performed similarly on all species.

Sulfentrazone alone at $90 \mathrm{~g} \cdot \mathrm{ha}^{-1}$ controlled Palmer amaranth $83 \%$ and control increased to $93 \%$ with increase in rate to $140 \mathrm{~g} \cdot \mathrm{ha}^{-1}$, but sulfentrazone at 112 $\mathrm{g} \cdot \mathrm{ha}^{-1}$ did not control Palmer amaranth nearly as well as F7583 at $1120 \mathrm{~g} \cdot \mathrm{ha}^{-1}$. Regardless of rate, sulfentrazone controlled tumble pigweed, kochia and puncturevine similar to F7583. However, foxtail millet control was significantly lower with sulfentrazone treatments (54\% to $76 \%$ ) compared to F7583 (89\% to $97 \%$ ). These results indicated that sulfentrazone alone is effective on broadleaf weeds but not on grass weeds and the $S$-metolachlor present in the premix of F7583 contributed to increased green foxtail control.

Among PRE treatments, lowest broadleaf weed control was observed with $S$-metolachlor at $806 \mathrm{~g} \cdot \mathrm{ha}^{-1}$. S-metolachlor at 1008 or $1266 \mathrm{~g} \cdot \mathrm{ha}^{-1}$ controlled Palmer amaranth, puncturevine, tumble pigweed and green foxtail as well as F7583 at $1120 \mathrm{~g} \cdot \mathrm{ha}^{-1}$, but was less effective onkochia. Pendimethalin at $1600 \mathrm{~g} \cdot \mathrm{ha}^{-1}$ provided similar control of all weed species as provided by the $896 \mathrm{~g} \cdot \mathrm{ha}^{-1}$ rate of F7583 except tumble pigweed. No treatment controlled puncturevine more than $85 \%$ and there was no significant difference among treatments.

Premixtures or tank mixtures of sulfentrazone containing treatments did not visibly injured sunflower anytime during the season (data not shown). Olson et al. (2011) [7] also observed negligible injury in sunflowers at Colby with sulfentrazone at 105 or $140 \mathrm{~g} \cdot \mathrm{ha}^{-1}$. On a silt loam soil, Kniss (2011) [9] reported 25\% and 36\% sunflower injury with sulfentrazone at 105 and 140 $\mathrm{g} \cdot \mathrm{ha}^{-1}$, respectively at $28 \mathrm{DAP}$; however, seed yields were not affected. Commercial standards $S$-metolachlor and pendimethalin also did not cause any injury.

At Colby, sunflower treated with F7583 treatments averaged across rates yielded 2.6-times more compared to sunflower in the non-treated control (Table 2). Sunflower treated with F7583 at $896 \mathrm{~g} \cdot \mathrm{ha}^{-1}$ yielded 2690 $\mathrm{kg} \cdot \mathrm{ha}^{-1}$ seed and no yield benefit was gained by increasing F7583 rate. Sunflower yields for both rates of tank mixed sulfentrazone plus $S$-metolachlor were similar to the yields of sunflower treated with F7583 at any rate. Yields of sunflower treated with sulfentrazone at 140 $\mathrm{g} \cdot \mathrm{ha}^{-1}$ were similar to F7583 treatments, whereas sulfentrazone at 90 or $112 \mathrm{~g} \cdot \mathrm{ha}^{-1}$ yielded $8 \%$ less compared to F7583 averaged across rates. Poor control of green foxtail $(<70 \%)$ might be the reason for reduced seed yields with sulfentrazone at 90 or $120 \mathrm{~g} \cdot \mathrm{ha}^{-1}$ (Table 2). Similarly, 15 and $25 \%$ lower seed yields were recorded for sunflower treated with $S$-metolachlor (across rates) and pendimethalin, respectively compared to F7583. It was evident from the weed control data that both $S$-metolachlor and pendimethalin were not as effective as F7583 in controlling Palmer amaranth and kochia.

This study indicated that F7583 at 1120 or $1400 \mathrm{~g} \cdot \mathrm{ha}^{-1}$ applied PRE controlled troublesome weeds like Palmer amaranth and kochia better than some commercial standard herbicides without causing visible crop injury. However, in drought prone areas like Kansas, lack of rainfall or insufficient soil moisture after PRE herbicides application is common and this may decrease the efficacy of herbicides. Probability of rainfall is greater earlier in the season when preplant herbicides typically are 
Table 2. Effect of F7583 applied preemergence on weed control and sunflower seed yields, Colby and Hays, KS, 2010.

\begin{tabular}{|c|c|c|c|c|c|c|c|}
\hline \multirow{3}{*}{ Treatments } & \multirow{2}{*}{ Rate } & $\begin{array}{l}\text { Palmer } \\
\text { amaranth }\end{array}$ & $\begin{array}{c}\text { Tumble } \\
\text { pigweed }\end{array}$ & Kochia & Puncturevine & Green foxtail & Seed yield \\
\hline & & Pooled & Pooled & Colby & Pooled & Pooled & Colby \\
\hline & $\mathrm{g} \cdot \mathrm{ha}^{-1}$ & ---------------. & ------ & ----\%"--- & -------------- & ------------ & $\mathrm{kg} \cdot \mathrm{ha}^{-1}$ \\
\hline Control & & - & - & - & - & - & 960 \\
\hline F7583 & 896 & 89 & 99 & 94 & 66 & 89 & 2690 \\
\hline F7583 & 1120 & 100 & 100 & 100 & 73 & 94 & 2500 \\
\hline F7583 & 1400 & 100 & 100 & 99 & 74 & 97 & 2380 \\
\hline Sulfentrazone $+S$-metolachlor & $90+806$ & 97 & 99 & 98 & 64 & 91 & 2200 \\
\hline Sulfentrazone $+S$-metolachlor & $112+1008$ & 96 & 99 & 100 & 68 & 93 & 2760 \\
\hline Sulfentrazone & 90 & 83 & 98 & 96 & 49 & 54 & 2320 \\
\hline Sulfentrazone & 112 & 80 & 93 & 97 & 62 & 68 & 2330 \\
\hline Sulfentrazone & 140 & 93 & 99 & 99 & 68 & 76 & 2960 \\
\hline S-metolachlor & 806 & 78 & 83 & 70 & 45 & 92 & 2090 \\
\hline$S$-metolachlor & 1008 & 93 & 99 & 84 & 50 & 88 & 2200 \\
\hline Pendimethalin & 1600 & 84 & 83 & 83 & 81 & 85 & 1900 \\
\hline $\operatorname{LSD}(\mathrm{P}=0.05)$ & & 15 & 13 & 15 & NS & 13 & 630 \\
\hline
\end{tabular}

applied. Hence, additional studies were done in 2011 to refine F7583 application time and rate.

\subsection{Year II}

At Colby, rainfall totaling $4.3 \mathrm{~cm}$ was received over a two day period immediately after preplant herbicide application and $3.6 \mathrm{~cm}$ rainfall was received 7 days after PRE herbicides were applied (data not shown). At Hays, nearly $4.3 \mathrm{~cm}$ rainfall was received within three days prior to preplant herbicide application with the next rainfall event $(3.1 \mathrm{~cm})$ occurring 15 days after preplant herbicide application. Rainfall totaling $2.9 \mathrm{~cm}$ was received over a three day period within hours after PRE herbicide application. At Manhattan, $6.5 \mathrm{~cm}$ of rainfall was received immediately after preplant application and $3.2 \mathrm{~cm}$ was received within 7 days period after PRE herbicides application. Kochia and puncturevine were predominate weed species at Colby. Palmer amaranth was the only predominate weed species in the Hays trial. Palmer amaranth, large crabgrass, stinkgrass (Eragrostis cilianensis) and giant foxtail (Setaria faberi) were major weeds at Manhattan.

\subsubsection{Palmer Amaranth Control}

At Hays, preplant-applied F7583 at $860 \mathrm{~g} \cdot \mathrm{ha}^{-1}$ controlled Palmer amaranth $86 \%$ and control increased with increase in rate (Table 3). F7583 at 1100 to $1840 \mathrm{~g} \cdot \mathrm{ha}^{-1}$ controlled Palmer amaranth $\geq 96 \%$. Preemergence-applied F7583, regardless of rate, controlled Palmer amaranth $\geq 95 \%$. Preemergence treatments looked slightly better than preplant treatments, but not significantly different. This trend was more conspicuous at Manhattan. The maximum palmer amaranth control achieved at Manhattan with preplant F7583 treatments was $70 \%$. The lowest rate of F7583 $\left(860 \mathrm{~g} \cdot \mathrm{ha}^{-1}\right)$ applied PRE controlled Palmer amaranth greater than any preplant rate (95 vs $\leq 70$ ). At both sites F7583 applied PRE controlled Palmer amaranth similarly, but the control with preplant treatments varied between two sites. Lower control of Palmer amaranth with F7583 applied preplant at Manhattan compared to Hays could be due to higher weed density (data not shown) and lower soil $\mathrm{pH}(6.8)$ than at Hays (7.8). Greater sulfentrazone adsorption occurs in soils with lower $\mathrm{pH}$ [10]. Sulfentrazone is a weak acid and its concentration in soil solution increases as soil $\mathrm{pH}$ increases and is available for root uptake by plants [11].

Both $S$-metolachlor at $1070 \mathrm{~g} \cdot \mathrm{ha}^{-1}$ and pendimethalin at $1600 \mathrm{~g} \cdot \mathrm{ha}^{-1}$ applied either preplant or PRE were considerably less effective on Palmer amaranth compared to F7583 treatments. They were more effective when applied PRE compared to preplant application.

\subsubsection{Kochia and Puncturevine Control}

Regardless of rate or application timing, F7583 treat- 
Table 3. Effect of F7583 applied 21 days preplant (DPP) or preemergence (PRE) on Palmer amaranth, kochia and puncturevine control in 2011.

\begin{tabular}{|c|c|c|c|c|c|c|}
\hline \multirow{3}{*}{ Treatment } & \multirow{3}{*}{ Time of application } & \multirow{2}{*}{ Rate } & \multicolumn{2}{|c|}{ Palmer amaranth } & \multirow{2}{*}{$\begin{array}{l}\text { Kochia } \\
\text { Colby }\end{array}$} & \multirow{2}{*}{$\begin{array}{c}\text { Puncturevine } \\
\text { Colby }\end{array}$} \\
\hline & & & Hays & Manhattan & & \\
\hline & & $\mathrm{g} \cdot \mathrm{ha}^{-1}$ & 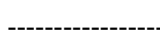 & ------ & & י--י-י-יר \\
\hline F7583 & $21 \mathrm{DPP}$ & 860 & 86 & 33 & 100 & 33 \\
\hline F7583 & $21 \mathrm{DPP}$ & 1100 & 96 & 33 & 100 & 40 \\
\hline F7583 & $21 \mathrm{DPP}$ & 1350 & 96 & 46 & 100 & 48 \\
\hline F7583 & $21 \mathrm{DPP}$ & 1840 & 99 & 70 & 100 & 50 \\
\hline$S$-metolachlor & $21 \mathrm{DPP}$ & 1070 & 33 & 0 & 38 & 5 \\
\hline Pendimethalin & $21 \mathrm{DPP}$ & 1600 & 37 & 48 & 63 & 38 \\
\hline F7583 & PRE & 860 & 95 & 95 & 100 & 45 \\
\hline F7583 & PRE & 1100 & 96 & 100 & 100 & 48 \\
\hline F7583 & PRE & 1350 & 100 & 100 & 100 & 40 \\
\hline$S$-metolachlor & PRE & 1070 & 86 & 73 & 58 & 35 \\
\hline Pendimethalin & PRE & 1600 & 73 & 87 & 66 & 35 \\
\hline $\operatorname{LSD}(\mathrm{P}=0.05)$ & & & 13 & 25 & 15 & 17 \\
\hline
\end{tabular}

ments maintained complete kochia control at Colby (Table 3). In a similar study at Lingle, Wyoming, F7583 applied PRE at 860 to $1350 \mathrm{~g} \cdot \mathrm{ha}^{-1}$ controlled kochia completely, but control for preplant treatments were much less than PRE treatments [12]. At Colby, S-metolachlor and pendimethalin applied preplant or PRE controlled kochia significantly less than F7583. There was no significant difference between preplant and PRE treatments of pendimethalin. S-metolachlor was more effective on kochia when applied PRE compared to preplant application. No treatment controlled puncturevine more than $50 \%$. Lowest puncturevine control (5\%) was observed with $S$-metolachlor applied preplant.

\subsubsection{Grass Weed Control}

None of the preplant treatments including F7583 were effective against large crabgrass, stinkgrass or giant foxtail at Manhattan (Table 4). F7583 applied PRE, regardless of rate, provided complete control of large crabgrass, $92 \%$ to $96 \%$ control of stinkgrass and $85 \%$ to $93 \%$ control of giant foxtail. Similar to these results, at Sydney, Nebraska, F7583 at 860 to $1350 \mathrm{~g} \cdot \mathrm{ha}^{-1}$ applied PRE controlled witchgrass (Panicumcapillare) $\geq 94 \%$, but the same rate applied preplant (4 weeks before planting) resulted in significantly less weed control [13]. It suggests the importance of time interval between preplant application of herbicide and planting. As the interval widens, the residual effect of F7583 may decrease and result in poor weed control. S-metolachlor applied PRE controlled large crabgrass and stinkgrass similar to F7583, but giant foxtail control (68\%) was lower compared to F7583 at any rate. Pendimetalin applied PRE controlled all grasses similar to F7583.

\subsubsection{Crop Injury and Seed Yields}

At all three locations, no treatment reduced sunflower plant population or visibly injured sunflower anytime during the season (data not shown). At Sidney, NE, above normal rainfall after preplant application of F7583 and again good amount of rainfall after PRE treatments resulted in $19 \%$ - $26 \%$ sunflower injury, but plants recovered fully within a few weeks [13]. In a high $\mathrm{pH}(8.15)$ silt loam soil, $64 \%$ - $75 \%$ injury was reported due to PRE application of F7583 at 27 DAT; however, injury declined to $9 \%-20 \%$ at 85 DAT and did not affect yields [12]. At Manhattan, treatments did not differ significantly in seed yields with each other and with untreated control (data not shown). On average, sunflowers treated with F7583 preplant and PRE yielded 1802 and 1772 $\mathrm{kg} \cdot \mathrm{ha}^{-1}$ seed, respectively.

\section{Conclusion}

Based on this study, premixed product F7583 (S-metolachlor \& sulfentrazone) applied preplant (3 weeks before planting) or PRE can safely be used in sunflower for weed control. Results indicated that, in neutral $\mathrm{pH}$ soils, F7583 at $1100 \mathrm{~g} \cdot \mathrm{ha}^{-1}$ or more applied preplant or PRE provided satisfactory control of kochia and Palmer ama- 
Table 4. Effect of F7583 applied 21 days preplant (DPP) or preemergence (PRE) on large crabgrass, stinkgrass and giant foxtail control at Manhattan, KS, 2011.

\begin{tabular}{|c|c|c|c|c|c|}
\hline \multirow{2}{*}{ Treatment } & \multirow{2}{*}{ Time of application } & Rate & Large crabgrass & Stinkgrass & Giant foxtail \\
\hline & & $g \cdot h a^{-1}$ & \multicolumn{3}{|c|}{ 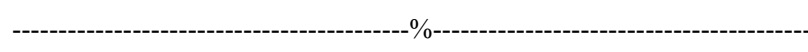 } \\
\hline F7583 & $21 \mathrm{DPP}$ & 860 & 5 & 5 & 5 \\
\hline F7583 & $21 \mathrm{DPP}$ & 1100 & 8 & 8 & 8 \\
\hline F7583 & $21 \mathrm{DPP}$ & 1350 & 45 & 35 & 28 \\
\hline F7583 & $21 \mathrm{DPP}$ & 1840 & 63 & 36 & 33 \\
\hline$S$-metolachlor & $21 \mathrm{DPP}$ & 1070 & 25 & 0 & 0 \\
\hline Pendimethalin & $21 \mathrm{DPP}$ & 1600 & 68 & 60 & 55 \\
\hline F7583 & PRE & 860 & 100 & 94 & 85 \\
\hline F7583 & PRE & 1100 & 100 & 92 & 90 \\
\hline F7583 & PRE & 1350 & 100 & 96 & 93 \\
\hline$S$-metolachlor & PRE & 1070 & 98 & 80 & 68 \\
\hline Pendimethalin & PRE & 1600 & 100 & 98 & 98 \\
\hline $\operatorname{LSD}(\mathrm{P}=0.05)$ & & & 26 & 21 & 16 \\
\hline
\end{tabular}

ranth. In slightly acidic soils, where greater herbicide adsorption is expected than high $\mathrm{pH}$ soils, PRE application of F7583 was more effective on kochia and grass weeds compared to preplant application. Results also indicated that F7583 can control troublesome weeds as effectively as tank mixed $S$-metolachlor plus sulfentrazone and performed much better than commercial standards pendimethalin and $S$-metolachlor especially on broadleaf weeds. However, puncturevine control was not commercially satisfactory with F7583. No crop injury or yield reductions were observed with F7583. Overall the study indicated that F7583 is a promising new herbicide for use in sunflower.

\section{Acknowledgements}

The authors thank FMC Corporation, National Sunflower Association and Kansas Sunflower Commission for their financial support to this project. Contribution number 13-175-J from the Kansas Agricultural Experiment Station.

\section{REFERENCES}

[1] USDA-NASS (US Department of Agriculture-National Agricultural Statistics Service), "Acreage-June 2011," USDA-NASS, Washington, 2011. http://usda01.library.cornell.edu/usda/nass/Acre//2010s/2 011/Acre-06-30-2011.pdf

[2] Anonymous, "National Sunflower Association Survey: Yield, Cultural Practices and Yield Limiting Factors," 2011. http://www.sunflowernsa.com/uploads/resources/631/201 1-sf-survey-final-report.pdf

[3] B. J. Johnson, "Effect of Weed Competition on Sunflower," Weed Science, Vol. 19, No. 2, 1971, pp. 378380.

[4] B. R. Durgan, A. G. Dexter and S. D. Miller, "Kochia (Kochiascoparia) Interference in Sunflower (Helianthus annuus)," Weed Technology, Vol. 4, No. 1, 1990, pp. 5256.

[5] J. D. Holman, A. J. Bussan, B. D. Maxwell, P. R. Miller and J. A. Mickelson, "Spring Wheat, Canola, and Sunflower Response to Persian darnel (Loliumpersicum) Interference," Weed Technology, Vol. 18, No. 3, 2004, pp. 509-520. doi:10.1614/WT-03-056R

[6] K. K. Hatzios, "Herbicide Handbook," Supplement to the 7th Edition, Weed Science Society of America, Champaign, 1998, p. 104.

[7] B. L. S. Olson, R. K. Zollinger, C. R. Thompson, D. E. Peterson, B. Jenks, M. Moechnig and P. W. Stahlman, "Pyroxasulfone with and without Sulfentrazone in Sunflower (Helianthus annuus)," Weed Technology, Vol. 25, No. 2, 2011, pp. 217-221. doi:10.1614/WT-D-10-00089.1

[8] P. W. Stahlman, B. L. S. Olson, C. R. Thompson and R. K. Zollinger, "Pyroxasulfone (KIH-485) for Weed Control in Sunflower," Proceedings of the 1st Australian Summer Grains Conference, Gold Coast, 21-24 June 2010.

[9] A. R. Kniss, "Spartan (Sulfentrazone) Herbicides for Residual Weed Control in Dryland Sunflower," Weed Research Report, Department of Plant Sciences, University of Wyoming, Laramie, 2011, pp. 45-47. http://w3.uwyo.edu/ akniss/Reports/2011_WeedReport.p df

[10] G. A. Ohmes and T. C. Mueller, "Sulfentrazone Adsorp- 
tion and Mobility in Surface Soil of the Southern United States," Weed Technology, Vol. 21, No. 3, 2007, pp. 796800. doi:10.1614/WT-06-185.1

[11] G. W. Kerr, P. W. Stahlman and J. A. Dille, "Soil pH and Cation Exchange Capacity Effects Sunflower Tolerance to Sulfentrazone," Weed Technology, Vol. 18, No. 2, 2004, pp. 243-247. doi:10.1614/WT-03-025R

[12] A. R. Kniss, "Weed Control and Crop Safety in Dryland Sunflower with Broadaxe herbicide," Weed Research
Report, Department of Plant Sciences, University of Wyoming, Laramie, 2011, pp. 49-51.

http://w3.uwyo.edu/ akniss/Reports/2011_WeedReport.p df

[13] Anonymous, "Evaluation of Broadaxe for Crop Safety and Weed Control in No-Till Sunflowers," 2011.

http://panhandle.unl.edu/c/document_library/get_file?uui $\mathrm{d}=\mathrm{f} 910 \mathrm{~b} 6 \mathrm{ae}-\mathrm{bf0d}-4 \mathrm{~b} 39-99 \mathrm{~d} 5-6 \mathrm{~b} 7 \mathrm{~b} 235 \mathrm{c} 6 \mathrm{e} 3 \mathrm{~d} \&$ groupId $=1$ 31817\&.pdf 